\title{
The 2007 caldera collapse at Piton de la Fournaise: new insights from multi-temporal structure-from-motion
}

\author{
Allan Derrien ${ }^{* \alpha, \beta}$, Aline Peltier ${ }^{\alpha, \beta}$, Nicolas Villeneuve $^{\alpha, \beta}, \gamma$, Thomas Staudacher ${ }^{\alpha, \beta}$ \\ ${ }^{\alpha}$ Université de Paris, Institut de physique du globe de Paris, CNRS, F-75005 Paris, France \\ $\beta$ Observatoire Volcanologique du Piton de la Fournaise, Institut de physique du globe de Paris, F-97418 La Plaine des Cafres, France

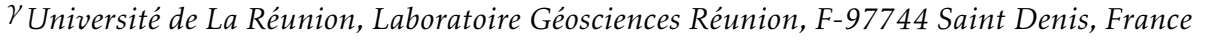

\begin{abstract}
We produced new multi-temporal Digital Elevation Models (DEMs) of the April 2007 summit collapse at Piton de la Fournaise from previously unused aerial photographs. This dataset reveals the precise temporal evolution of the collapsed volume and caldera morphological changes during the event. It provides a unique opportunity to study caldera formation, one of the most hazardous natural phenomena, for which relatively little scientific and quantified information is available. During this rare example of observed caldera formation, the summit started to collapse four days after the onset of a high-volume eruption at an unusually low elevation (at 20:48 UTC on April $\left.5^{\text {th }}\right)$. Our new data show that during the first 30 hours, collapse was relatively fast $\left(840 \mathrm{~m}^{3} \mathrm{~s}^{-1}\right.$ average), and continued for at least the following 12 days, at a slower rate $\left(46 \mathrm{~m}^{3} \mathrm{~s}^{-1}\right.$ average), which had not previously been reported. On April $19^{\text {th }}$, the collapse reached $96 \%$ of its final volume, while the remaining $4 \%$ was probably attained by May $1^{\text {st }}$ (end of lava emission at the vent). New infrared 3D mapping of the caldera floor made a year after the event demonstrates that post-collapse hydrothermal activity in the caldera is closely associated with the main ring faults active during the collapse, which are now preferential paths for fluids to reach the surface.
\end{abstract}

Keywords: Caldera; Collapse; 4D mapping; Piton de la Fournaise; Geodynamics; Volcano

\section{InTRODUCTION}

In volcanic systems, rapid withdrawal of large magma volumes from reservoirs can lead to the formation of calderas - broad depressions at the top or on the sides of volcano flanks. These large but recurring events pose multiple hazards to neighboring communities (e.g. caldera collapses, summit instabilities, high gas fluxes, ash plumes, ash deposits, rapid and extended lava flows in distal areas). Even for calderas of classic morphologies on basaltic shield volcanoes, scientific records of observations during their formation are rare: Killauea volcano, Hawai'i, in 1960 [Delaney and McTigue 1994]; Fernandina volcano, Galápagos, in 1968 [Simkin and Howard 1970]; Miyakejima, Japan, in 2000 [Geshi et al. 2002]; Piton de la Fournaise volcano (PdF), La Réunion, in 2007 [e.g. Staudacher et al. 2009]; Bárðarbunga volcano, Iceland, in 2014 [e.g. Gudmundsson et al. 2016]; and Kîlauea again in 2018 [e.g. Neal et al. 2019]. Detailing and understanding collapse mechanisms may lead to significant breakthroughs in volcano dynamics science. In particular, detailed measurement of the collapsed volumes and precise mapping of ring faults during and after the caldera formation is of paramount importance when determining the precise geometry and location of an underlying magma reservoir. The April 2007 col-

\footnotetext{
${ }^{*}$ Corresponding author: allan.derrien@yahoo.fr
}

lapse of the PdF summit is part of a wide range of collapse processes due to the withdrawal of a large volume of magma from an underlying reservoir. Its relatively small volume (approximately $0.1 \mathrm{~km}^{3}$ according to Staudacher et al. [2009]) places it at the "small" end-member of caldera collapses, with much larger examples observed at other locations (e.g. 1 to $2 \mathrm{~km}^{3}$ at Fernandina volcano in 1968 [Acocella et al. 2015] or $1.8 \mathrm{~km}^{3}$ at Bárðarbunga volcano in 2014 [Gudmundsson et al. 2016]).

The style of the April 2007 event has been suggested to represent a plate or "piston" mechanism (following the caldera end-members proposed in the literature [e.g. Acocella 2007; Cole et al. 2005; Lipman 1997]), where a single main rock column above the reservoir is destabilised and collapses, coeval with voluminous magma withdrawal. Such events are triggered by magma exiting a magma reservoir through intrusions (dykes and/or sills). This intrusion may reach the surface far from the source reservoir (e.g. $>45 \mathrm{~km}$ at Bárðarbunga in 2014 [e.g. Gudmundsson et al. 2016]), with two implications: (1) the length of the intrusion implies a significant volume of magma is tapped from the reservoir during the intrusion process and (2) the location of the vent, far from the reservoir, is often also at lower elevation, favouring rapid and voluminous lava emission (the difference in altitude between the source reservoir and the vent in this case being smaller 
than for eruptions occurring at higher elevation close to the summit). Thus, collapses at volcano summit are often coeval with the beginning of an eruption located far from the usual active center. In later stages of the caldera formation, it is also possible that magma uses the caldera faults, sometimes rooted at the reservoir roof, as preferential pathways to reach the surface [e.g. Kennedy et al. 2018]. In these cases, the collapse process may also be coeval with, or precede, smaller volume, intra-caldera eruption(s) (e.g. the case of several eruptions inside PdF's Cratère Dolomieu in 2008-2009 [Staudacher 2010]).

Piton de la Fournaise is located in the southwestern Indian Ocean (Figure 1A). This hotspot basaltic shield volcano has undergone a series of summit caldera collapses in the last three centuries [e.g. Michon et al. 2013; Peltier et al. 2012], each forming a depression subsequently filled with the products of following summit eruptions. The latest of these events (Figure 1B, C) began on April 5 $5^{\text {th }}, 2007$ (20:48 UTC) and was associated with an unusually voluminous distal eruptive phase starting on April $2^{\text {nd }}$ and ending on May $1^{\text {st }}$. More than $140 \times 10^{6} \mathrm{~m}^{3}$ of lava have been emitted according to Staudacher et al. [2009] and $240 \times 10^{6} \mathrm{~m}^{3}$ according to Roult et al. [2012]. These large volumes widely emptied the shallow magma reservoir located at a depth of about 1-2 km [Michon et al. 2011; Michon et al. 2007; Michon et al. 2009; Muro et al. 2014; Peltier et al. 2009; Staudacher et al. 2009]. This event was well documented by ground deformation [Peltier et al. 2009], seismicity [Fontaine et al. 2014; Massin et al. 2011], extrusion rate [Coppola et al. 2009] and gas emission [Gouhier and Coppola 2011; Muro et al. 2014; Tulet and Villeneuve 2011] datasets. No technique or tool to directly measure the evolution of the collapse morphology and volume were available in situ at PdF. In this study, we present the first quantified observations of the geomorphological evolution of a volcanic caldera during its formation. Helped by recent developments in image matching software, we produced an unprecedented series of high-resolution Digital Elevation Models (DEMs) of the summit from aerial photographs taken during its collapse. These DEMs reveal the caldera volume evolution during the first fourteen days following the initiation of the collapse. With the addition of complementary aerial infrared data from the Observatoire Volcanologique du Piton de la Fournaise acquired about a year after the collapse, we bring new light to the collapse structure and dynamics.

\section{Methods}

2.1 Production of multi-temporal DEMs of the caldera

The complete 2007 aerial photography dataset used in this study comprises (1) seven aerial photography cam- paigns (pre- and syn-collapse on January $10^{\text {th }}$, April $7^{\text {th }}$ [two sets], $10^{\text {th }}, 12^{\text {th }}, 17^{\text {th }}$ and $\left.19^{\text {th }}\right)$, (2) a postcollapse set of 52 pictures (A.I.G.L.*; taken April $12^{\text {th }}$, 2008 and also used to georeference the other sets) and (3) a set of 130 post-collapse infrared images (May $5^{\text {th }}$, 2008). Except in the case of the A.I.G.L. campaign (which used automated photography and a camera set beneath an airplane), the photographs were acquired manually by different operators (Table 1) from an ultralight airplane flying roughly between 200 and 600 meters above the caldera rim (these values are different from the flying altitude values given in Photoscan reports, which are computed from the average point cloud to camera distance). Photographs with sufficient overlap were selected for structure-from-motion (SfM) processing. SfM is a technique that enables 3dimensional digital models to be built of real objects from multiple-view photographs [e.g. Koenderink and van Doorn 1991]. We processed the 9 datasets with Agisoft Photoscan Pro (V.1.2.3), a software solution that has efficiently yielded precise and reliable results in previous studies [e.g. Chandler et al. 2016; Frankl et al. 2014; Jaud et al. 2016] and notably in the case of PdF [Derrien et al. 2015; Derrien et al. 2018]. The Photoscan reports are available (open access) in Derrien and Villeneuve [2018]. For each dataset, a 3D model (point cloud) was produced (Table 1). Georeferencing followed three steps: (1) to georeference the April 2008 survey, the field coordinates of 39 ground control points (GCPs) were measured by GNSS, and used in the SfM processing. (2) From the resulting model, positions of 25 different features were extracted. (3) The coordinates of these features were used to georeference the other surveys. All models were thus co-referenced so that the exported DEMs could be compared. Note that GCPs were not included as control measurements in the bundle adjustment, but only to scale, rotate and translate the models (i.e. there were no independent check points). Seven high-resolution ( 0.5 to $2 \mathrm{~m}$ ) subsidence maps (or differential DEMs) during and after the collapse process were ultimately produced (Figure 2).

\subsubsection{Volumes and uncertainties}

Caldera volumes at different time steps were computed from the differential DEMs, by integration of the values over the caldera surface. Due to the uncertainty in GCP locations on the photographs and to errors in the photogrammetric models, the final co-referencing of the models yielded a mean absolute position error (i.e. the mean distance, in a model, between input coordinates and virtual coordinates for GCPs) of $0.52 \mathrm{~m}$ to $3.01 \mathrm{~m}$, mostly in the $\mathrm{z}$ component. Considering the $0.795 \mathrm{~km}^{2}$ surface of the summit caldera, this implies that the caldera successive caldera volumes were estimated with a $2.4 \times 10^{6} \mathrm{~m}^{3}$ maximum uncertainty.

* "Acquisition Information Géo-Localisée” (former french private aerial photogrammetry company). 


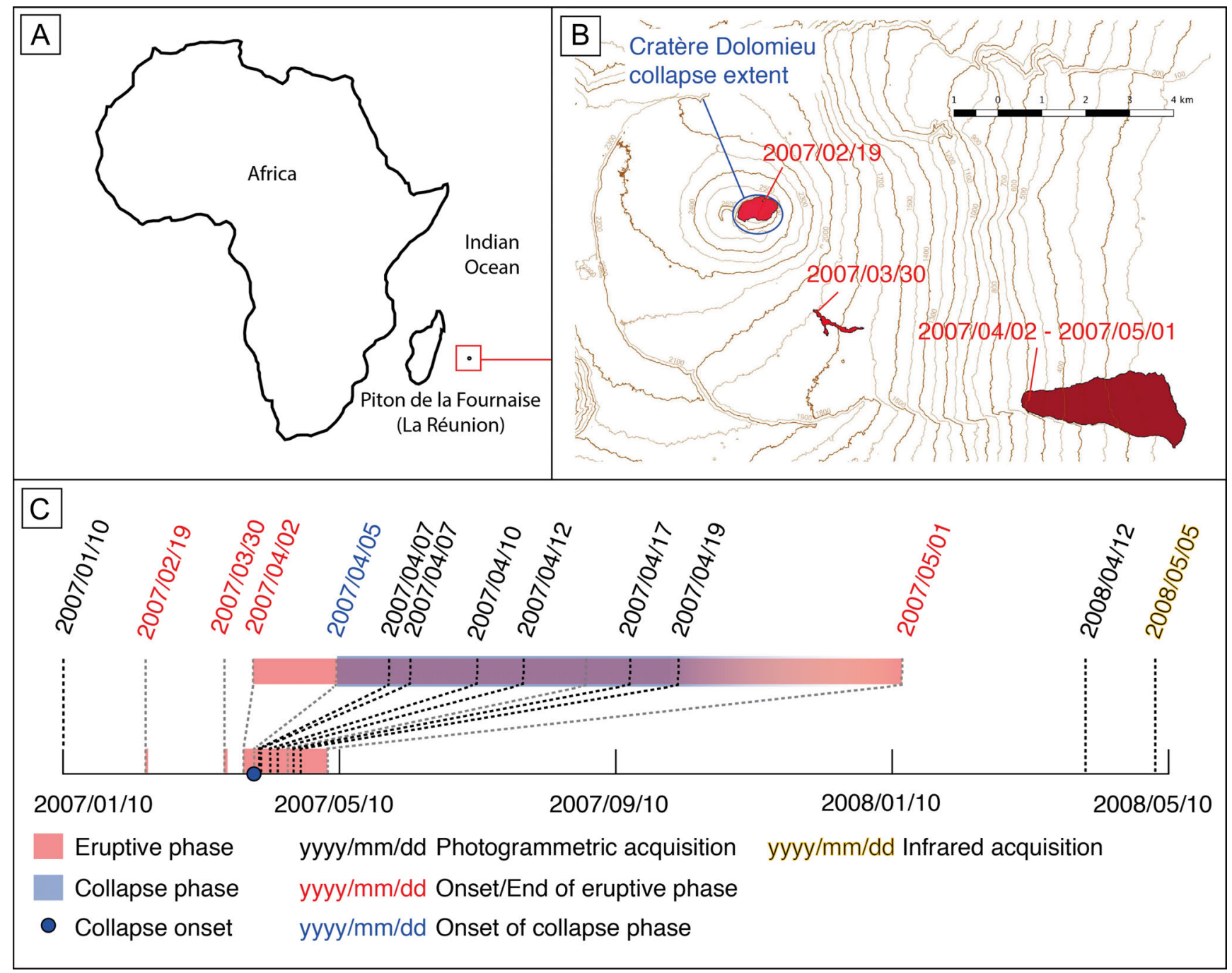

Figure 1: [A] Location of Piton de la Fournaise volcano. [B] Location of the April 2007 Cratère Dolomieu collapse and maps of the 2007 lava flows. [C] Timeline of the Piton de la Fournaise activity (eruptions and collapse) during the period of study. The dates of the aerial surveys used in this study are also reported.

\section{Results}

3.1 Morphological evolution of the caldera from the multi-temporal DEMs

During the first 6 days of the collapse (April $5^{\text {th }}$ to $10^{\text {th }}$ ), the whole Cratère Dolomieu area subsided (Figure 2AD). After April $10^{\text {th }}$, some terraces to the south and to the east did not display further subsidence (Figure 2EG), but most of the caldera area continued to subside until at least April $19^{\text {th }}$ (e.g. $6 \mathrm{~m}^{3} \mathrm{~s}^{-1}$ between April $17^{\text {th }}$ and April $\left.19^{\text {th }}\right)$. In some parts, the newly formed cliff became unstable, leading to rockfalls within the caldera walls (from $1 \times 10^{3}$ up to $809 \times 10^{3} \mathrm{~m}^{3}$ ). These rockfalls occurred mainly in the northwest and west of the caldera. After April 19 ${ }^{\text {th }}$, only the northern half of the caldera (Figure $2 \mathrm{H}$ ) continued to subside at a very low rate $\left(<6 \mathrm{~m}^{3} \mathrm{~s}^{-1}\right)$ until an unknown date. Between April $19^{\text {th }}, 2007$ and April $12^{\text {th }}, 2008$, the caldera volume had increased by $4.6 \times 10^{6} \mathrm{~m}^{3}$, and a few sec- tors in the northwestern cliff had detached and created deposits inside the caldera. There was a clear difference in behaviour between the northwest of the caldera (a quick collapse within the perimeter of the inner ring fault, not associated with terraces) and the south and east (a slower collapse associated with terraces and outer ring faults). These differences helped to map the surface trace of the faults at different stages of the caldera formation process (e.g. Figure 2I).

\subsection{Temporal evolution of the caldera volume}

The DEMs of the caldera showing the morphology at different stages of the April 2007 collapse allow us to measure a persistent subsidence several days after the onset of the event (Figure 3). After April $5^{\text {th }}$ and $6^{\text {th }}$, the subsidence rate followed an exponential decay trend (i.e. slowing of the caldera volume increase as shown on Figure 3C). On April $7^{\text {th }}, 2007$, at 2:40 UTC, or 30 
Table 1 - Details of the ultralight airplane aerial photography campaigns (more complete information is available in the Photoscan reports presented in Derrien et al. [2018]) and extracted topographic data used in this study. Photographs: number of photographs in the survey. DEM: resolution in meters. AMS: Absolute Mean Shift, mean absolute georeferencing shift between model and GCPs (as a measure of the georeferencing error [James et al. 2017]. GCP type is 'land' when the GCP location has been retrieved on the reference model, and 'target' when it has been measured in situ, at the time of acquisition, with GNSS measurements in static-rapid mode.

\begin{tabular}{ccccccccc}
\hline $\begin{array}{c}\text { Date } \\
\text { (YYYY/MM/DD })\end{array}$ & Camera & Photos & Operator & DEM $(\mathrm{m})$ & GCPs & Type & AMS (m) & Remarks \\
\hline $2007 / 01 / 10$ & DSC-V3 & 38 & T. Staudacher & 0.66 & 9 & Land & 1.86 & Pre-collapse \\
$2007 / 04 / 07$ & unknown & 17 & L. Ferlicot & 0.37 & 8 & Land & 2.9 & Syn-collapse \\
$2007 / 04 / 07$ & DSC-V3 & 34 & T. Staudacher & 0.79 & 5 & Land & 0.87 & Syn-collapse \\
$2007 / 04 / 10$ & DSC-V3 & 107 & T. Staudacher & 0.46 & 6 & Land & 3.01 & Syn-collapse \\
$2007 / 04 / 12$ & DSC-V3 & 66 & T. Staudacher & 0.43 & 7 & Land & 2.15 & Syn-collapse \\
$2007 / 04 / 17$ & DSC-V3 & 154 & T. Staudacher & 0.47 & 8 & Land & 1.39 & Syn-collapse \\
$2007 / 04 / 19$ & DSC-V3 & 147 & T. Staudacher & 1.17 & 6 & Land & 3.01 & Syn-collapse \\
$2008 / 04 / 12$ & Phase One & 50 & A.I.G.L & 0.49 & 39 & Targets & 0.52 & Post-collapse \\
$2008 / 05 / 05$ & FLIR & 29 & T. Staudacher & 2.11 & 4 & Land & 45 & Infrared \\
\hline
\end{tabular}

hours after the earthquake considered as the collapse initiation on April $5^{\text {th }}$, the caldera volume was measured to be $90.8 \times 10^{6} \mathrm{~m}^{3}$. This volume corresponds to an average volume loss of $840 \mathrm{~m}^{3} \mathrm{~s}^{-1}$ between April $5^{\text {th }}$ (20:48 UTC) and April $7^{\text {th }}$ (02:40 UTC). Twelve days later, on April 19 $19^{\text {th }}, 2007$, the caldera volume was $121.6 \times 10^{6} \mathrm{~m}^{3}$ (average volume loss of around $\left.105 \mathrm{~m}^{3} \mathrm{~s}^{-1}\right)$. This represented $71.9 \%$ and $96.4 \%$, respectively, of the final amount of $126.2 \times 10^{6} \mathrm{~m}^{3}$, measured on the April 12 $2^{\text {th }}, 2008$ DEM.

\subsection{Post-collapse thermal mapping}

The thermal mapping on May $5^{\text {th }}, 2008$, revealed further morphological clues relating to the caldera's structure. The spatial distribution of temperature inside the caldera showed a ring of thermal anomalies. This thermal ring, where temperature was between 20 and $39^{\circ} \mathrm{C}$ greater than the surrounding rock average temperature (Figure 4), circled the northern half of the caldera. It formed a kidney-like shape (as seen from above) running along the cliff of the Cratère Dolomieu mostly between 2300 and $2340 \mathrm{~m}$ a.s.l. Furthermore, we noted three distinct secondary thermal zones, in the southwest and south of the caldera Figure 4C). This thermal belt and the associated secondary thermal zones were still observed in 2017 (e.g. Figure 4, inset of December $\left.31^{\text {st }}, 2017\right)$.

\section{Discussion}

\subsection{Caldera volume and main caldera faults}

Our new dataset enables us to quantify the caldera's final volume at $126.6 \pm 2.1 \times 10^{6} \mathrm{~m}^{3}$, higher than, but in relatively good agreement with previous studies $\left(96 \times 10^{6} \mathrm{~m}^{3}\right.$ from Aster stereo-imagery and $100-120 \times 10^{6} \mathrm{~m}^{3}$ from field surveys Urai et al. [2007]). Lava emission volumes from the vent at low elevation were available at the time of the eruption, but were found not reliable enough to provide a scientifically relevant comparison with collapsed volume measurements (as they were derived from satellite radiance measurements instead of direct SfM 3D modeling; [Coppola et al. 2009]).

Many causes of caldera collapse can be found in the literature. The two main models link the caldera to a failure of the structure lying above a magma reservoir as a consequence of (1) an overpressure in the reservoir leading to fractures in the roof [e.g. Gudmundsson et al. 1997] or (2) an underpressure following a large magma withdrawal [e.g. Roche et al. 2000; Staudacher et al. 2009]. In the case of the April 2007 collapse at PdF, numerous geophysical parameters suggest underpressure from magma withdrawal [Staudacher et al. 2009]. Unusually high fountaining at the low-elevation vent and a strong increase in the eruptive tremor on April $5^{\text {th }}$, a few hours before the onset of the collapse [Staudacher et al. 2009], suggest unusually high magma extrusion rates prior to the collapse. Furthermore, GNSS permanent stations showed a significant deflation of the summit during the days preceding the collapse (April $2^{\text {nd }}$ to $5^{\text {th }}$; [Peltier et al. 2009]), strengthening the hypothesis of a large amount of magma being withdrawn from the shallow reservoir located below the summit. Calderas are generally considered to be delimited by a set of concentric faults (ring faults) linking the failure of the reservoir roof to the collapse structure at the surface [e.g. Acocella 2007; Gudmundsson 1988; Michon et al. 2009; Walker 1984]. These faults can be normal (inward-dipping), vertical or reverse (outward-dipping), depending on the models and location [Burchardt and Walter 2010; Gudmundsson et al. 2016; Roche et al. 2000]. They can be divided into 

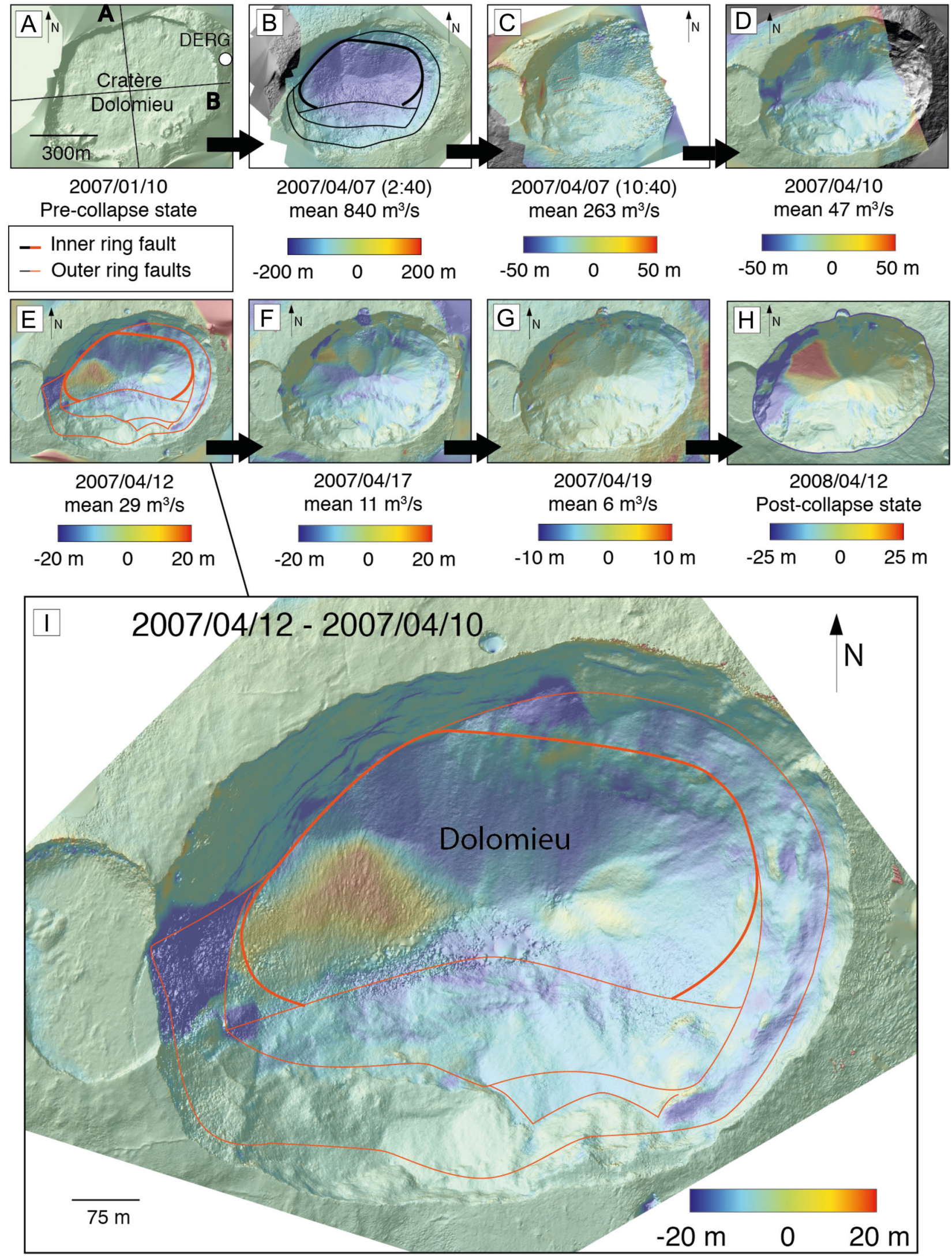

Figure 2: Evolution of subsidence inside the Cratère Dolomieu during and after the collapse, from vertical differences between consecutive DEMs. A and B on [A] are the locations of the cross-sections shown in Figure 3A, B. Rates are obtained by dividing the volume difference by the time period between two acquisitions. The thick and thin red contours on [E] and [I] are the outlines of the IRFs (Inner Ring Faults) and ORFs (Outer Ring Faults), respectively, reported in Figure 4B. 

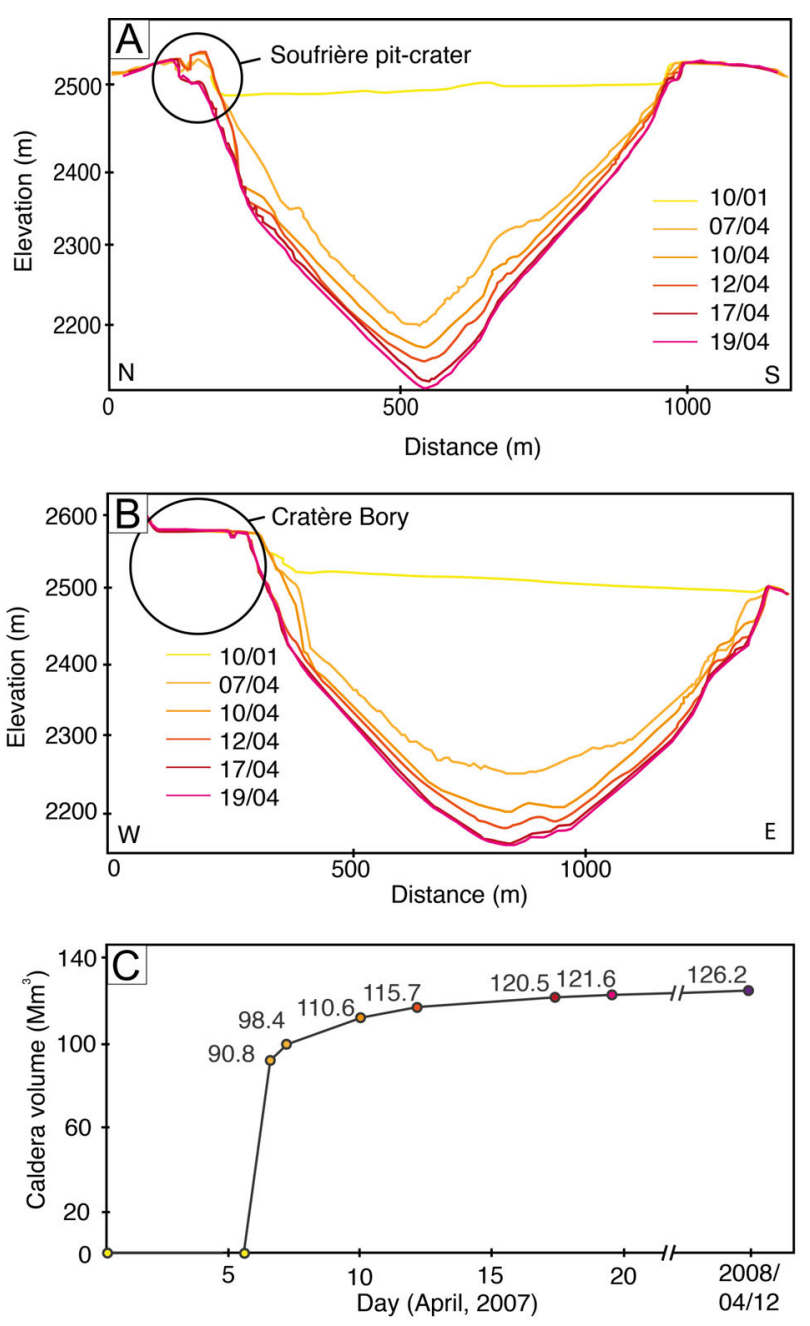

Figure 3: [A] N-S cross-sections of the successive DEMs made for 2007, with dates given in MM/DD format. [B] E-W cross-sections of the successive DEMs made for 2007. [C] Time series of the caldera volume evolution. See location of the cross-sections on Figure 2A.

two categories: the inner ring fault (IRF), and outer ring faults (ORF) that can develop outside the IRF as the collapse goes on. In the case of the PdF April 2007 collapse, Michon et al. [2007] showed an initial ring fault with a sub-circular shape centred in the northwestern part of the caldera, associated later with outer ring faults to the south and east, which eventually define the final extent of the caldera

With our new data, we were able to map the ring faults active during the collapse, and link them to the aforementioned broader collapse models. Figure 4 shows the spatial evolution of these faults and their associated terraces with a selection of time steps, deduced from the April $6^{\text {th }}$ aerial photograph (Figure 4A) and the DEMs we produced for April $7^{\text {th }}$ and $12^{\text {th }}$ (Figure 2). On April $6^{\text {th }}$, the IRF (Figure 4A, B), centred in the north-western part of the caldera, was completed by a set of ORFs in the south and east, delimiting three main terraces (Et, St1 and St2). On April $7^{\text {th }}$ St1 had
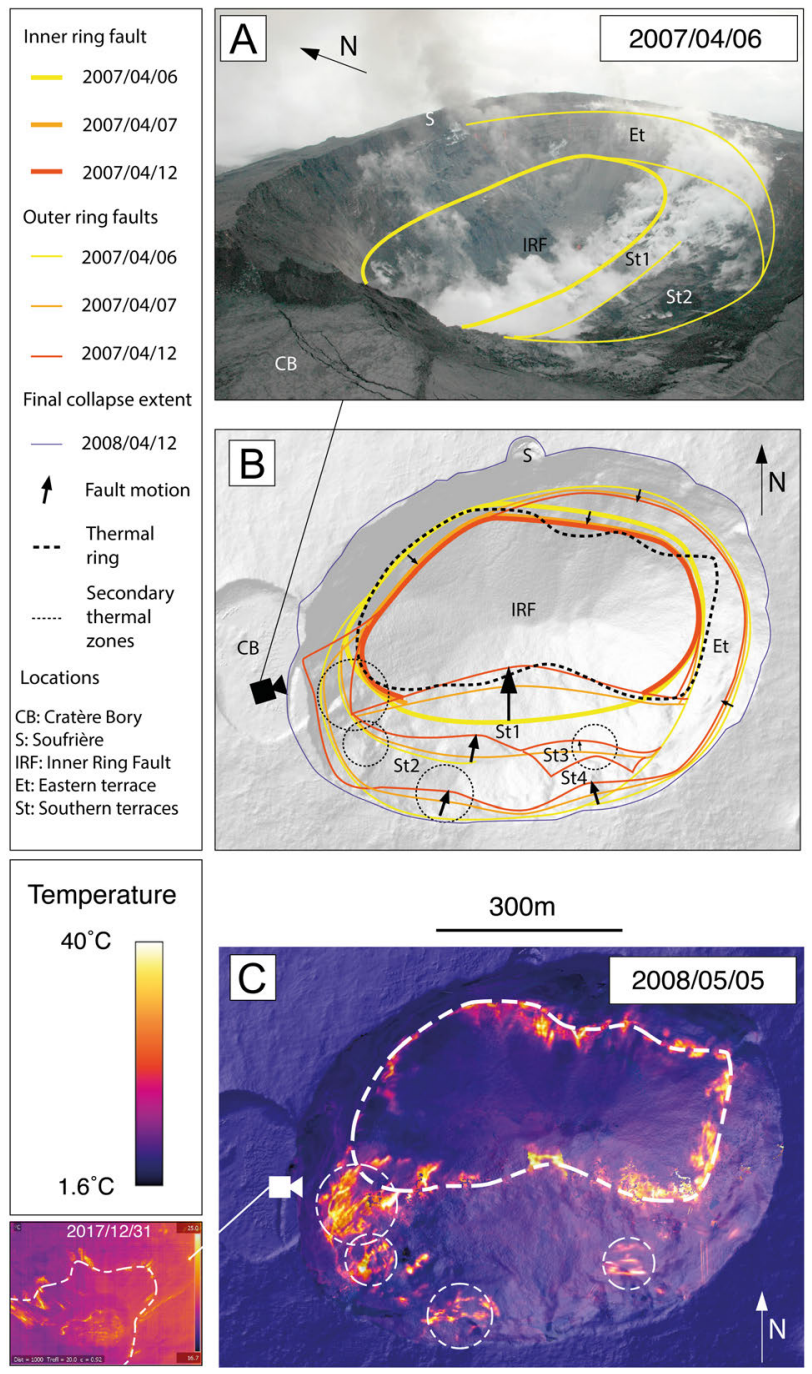

Figure 4: [A] Interpreted aerial photograph, courtesy of Peloton de Gendarmerie de Haute Montagne (PGHM), from the west of the Cratère Dolomieu on April $6^{\text {th }}$, 2007. [B] Temporal and spatial evolution of the structures associated with the April 2007 Cratère Dolomieu collapse, as identified on [A] and on Figure 2. Note the progressive appearance of the terraces associated with development of the outer ring faults, with Et, St 1 and St 2 created between April $5^{\text {th }}$ and $6^{\text {th }}$, St 3 created between April $6^{\text {th }}$ and $7^{\text {th }}$, and St 4 created between April $7^{\text {th }}$ and $12^{\text {th }}$. [C] Thermal orthoimage of the Cratère Dolomieu on May $5^{\text {th }}, 2008$. The inset shows a thermal image of the caldera taken from the west on December $12^{\text {th }}, 2017$.

subsided and moved northward, giving the IRF a kidney shape. The other terraces had also moved towards the centre of the caldera (Figure $4 \mathrm{~B}$ ) and the fault at the base of St 2 had significantly propagated eastward. On April 12 $2^{\text {th }}$, two new terraces appeared in the southwest and all the structures had again moved towards the centre of the caldera. The final area of Cratère Dolomieu $\left(0.788 \mathrm{~km}^{2}\right.$, versus $0.729 \mathrm{~km}^{2}$ before the col- 
lapse) was defined on the April $12^{\text {th }}, 2008$ DEM, after complete stabilization of the caldera floor (Figure 5E).

The evolution of the caldera morphology was characterized by the development of a strong N-S and weak $\mathrm{E}-\mathrm{W}$ asymmetry. The southern terraces moved sufficiently northward to cover the initial surface trace of the IRF. This caldera morphology is consistent with models proposed for collapses with high roof aspect ratios (i.e. upward propagation of vertical faults surrounding the reservoir, becoming slightly to significantly reverse (outward-dipping) close to the surface, [e.g. Holohan et al. 2011; Roche et al. 2000]), as would be expected at PdF (where the reservoir extent is thought to have a radius of about $500 \mathrm{~m}$ at around $2 \mathrm{~km}$ below the summit [e.g. Michon et al. 2009; Peltier et al. 2008]). After the end of the caldera formation process, its rim remained unstable and still produced hazardous rockfalls, especially in its northwestern quarter [details in Derrien et al. 2018].

4.2 Active faults during the caldera formation and their relationship with the post-collapse hydrothermal activity

Based on our DEMs, we propose the following model for development of the shallow subsurface caldera structure (Figure 5). First, following the propagation of the IRF to the former caldera floor, a collapse event was initiated on April $5^{\text {th }}$ (first collapse increment at 20:48 UTC, [Staudacher et al. 2009]). On April $6^{\text {th }}$, the central structure, delimited by the reverse IRF, had subsided significantly (as proposed by previous studies based on geophysical parameters, it behaved as a coherent block [e.g. Michon et al. 2009; Staudacher et al. 2009]). This behavior is in good agreement with those observed in sandbox analogue models of this type of caldera formation (in the case of magmatic reservoirs with high roof aspect ratios [e.g. Acocella 2007; Holohan et al. 2011; Roche et al. 2000]). The ring fault network was completed in the south and east by a normal ORF [Michon et al. 2009]. On April $12^{\text {th }}$, the normal ORF network increased in density so that the collapse extended further (in particular in the south). Debris filled the bottom of the caldera, so that the initial trace of the IRF was no longer exposed. We propose that a low-dipping reverse fault in the south, possibly as an extension of the southern IRF, was responsible for the significant northward displacement of St1 (Figure 5C).

The thermal mapping of the caldera's floor carried out on May $5^{\text {th }}, 2008$, revealed a thermal ring closely matching the IRF in the west, north and east, and the base of St1 in the south (Figure 4B, C). We thus propose that this thermal ring follows the IRF at depth. In March 2008, field observers reported that 70-80 \% of the thermal ring displayed fumarolic activity [Staudacher 2010], so that the thermal anomaly seems linked to hydrothermal fluid circulation in the caldera. This is consistent with models detailed by Stix et al. [2003] and
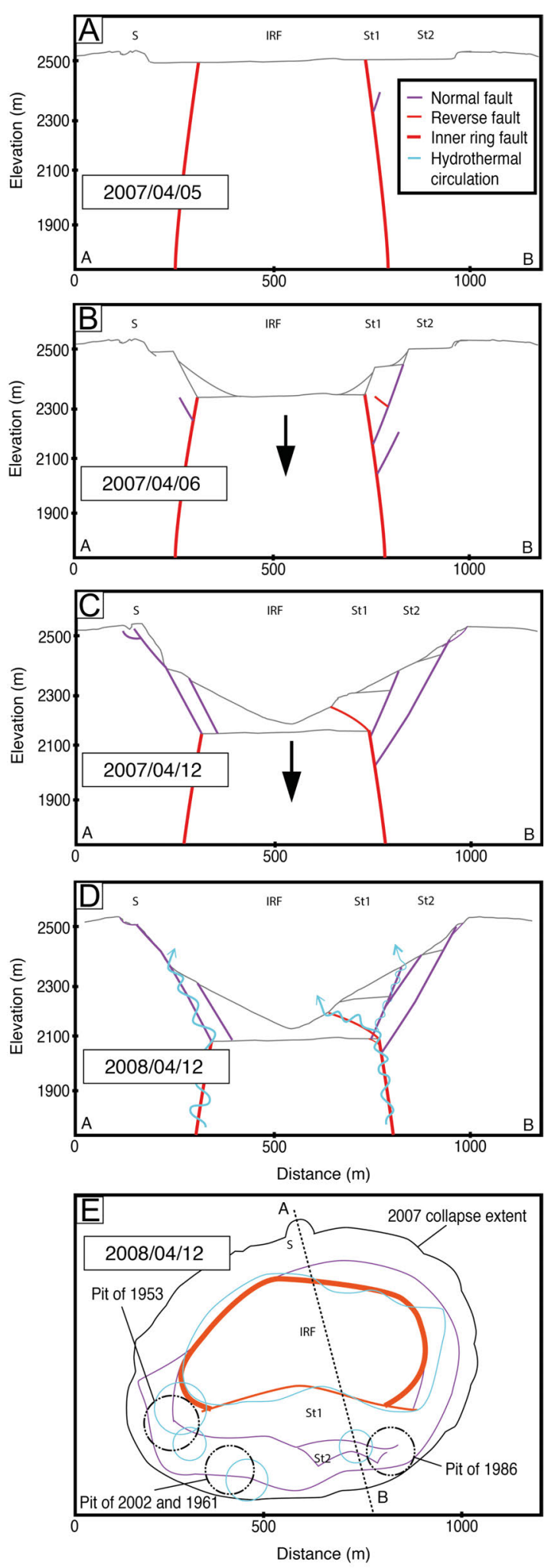

Figure 5: Interpretation of the temporal evolution of the April 2007 Dolomieu collapse on [A] April 5 ${ }^{\text {th }}$, [B] April $6^{\text {th }},[C]$ April $12^{\text {th }}, 2007$ and [D] April $12^{\text {th }}, 2008$ after complete cessation of the collapse mechanism. [E] Related interpretative map as observed on April $12^{\text {th }}$, 2008. S: Soufrière pit-crater, IRF: Inner Ring Fault, St1: Southern terrace 1, St2: Southern terrace 2. 
Garden et al. [2017], where flow of hydrothermal fluids preferentially follows pre-existing faults. The three other distinct secondary thermal zones (Figure 4C) seem to be located on the southern ORFs, and close to the location of four older pit-crater events $(1953,1961$, 1986 and 2002) at the summit of PdF (Figure 5E). These secondary thermal zones are more spatially diffuse than the main thermal ring, therefore inter-granular fluid flow may happen inside intra-caldera breccia at these locations (a process also evidenced by Garden et al. [2017]). A well-developed hydrothermal system is inferred below the summit [e.g. Barde-Cabusson et al. 2012; Dumont et al. 2019; Lénat et al. 2012]. It thus seems likely that hydrothermal fluids preferentially use the April 2007 faults to reach the surface, and mainly the most damaged areas (i.e. the IRF and the location of previously collapsed structures). As suggested by previous authors [Chaput et al. 2019; Peltier et al. 2012], in the case of Piton de la Fournaise, this hydrothermal circulation would result in rock alteration and the reduction of cohesion and material strength at depth, leading to zones more prone to fail. These zones of weakness are clearly visible in resistivity models [Dumont et al. 2019; Lénat et al. 2000], and would therefore have been active over a long time and could destabilize regularly.

\section{Conclusion}

Our new multi-temporal Digital Elevation Models (DEMs) of the April 2007 summit collapse at Piton de la Fournaise allows us:

1. to assess the spatio-temporal evolution of the caldera throughout the event (both its volume increase with a $2.1 \times 10^{6} \mathrm{~m}^{3}$ uncertainty and its morphology), making it possible to demonstrate that the collapse process lasted longer (at least 12 days) than previously thought;

2. to assess the precise location, geometry and role of the caldera ring faults. The surface trace of the initial ring fault was still mostly visible in 2019 in the west, south and east of the caldera, but was masked early in the collapse process by terraces and debris in the south; and

3. to identify a thermal anomaly that closely matches the caldera ring faults. Volcanic fluids preferentially used these faults to propagate from depth to the surface. Whether these fluids were directly transferred from the magmatic reservoir or just produced by very shallow hydrothermal circulation remains, however, to be determined.

Overall, very little dynamic geomorphological information is currently available for collapse processes on volcanoes, which are amongst the most spectacular and hazardous natural phenomena. This study provides multiple new insights (i.e. details of the temporal evolution of the caldera volume, precise mapping of faults active during the collapse and of thermal anomalies inside the caldera) into the formation process of the Piton de la Fournaise summit caldera, helping to further understand the relationship between faulting, hydrothermal circulation and collapse dynamics for this type of process worldwide.

\section{Acknowledgements}

We warmly thank Lucette Ferlicot for her precious set of aerial photographs taken on April $7^{\text {th }}$. Other data presented in this paper were collected by Observatoire Volcanologique du Piton de la Fournaise, Institut de Physique du Globe de Paris, UMR 7154 CNRS (OVPF/IPGP). Part of this work was supported by the ANR (Agence Nationale de la Recherche) through the SLIDEVOLC project (contract number ANR-16-CE04004-01). This is IPGP contribution number 4128.

\section{Author contributions}

A. Derrien undertook the data processing. A. Peltier and $\mathrm{N}$. Villeneuve were in charge of the supervision of the study. All authors contributed to the discussion and to writing the paper.

\section{Data AVailability}

The processing reports are available in the following open access repositories:

DOI: $10.13140 / \mathrm{RG} \cdot 2.2 .30360 .70403$,

DoI: $10.13140 / \mathrm{RG} \cdot 2 \cdot 2.27005 .26086$,

DOI: $10.13140 / \mathrm{RG} \cdot 2 \cdot 2.11905 .76647$,

DoI: $10.13140 / \mathrm{RG} \cdot 2.2 .19455 .51367$,

DoI: $10.13140 / \mathrm{RG} \cdot 2 \cdot 2 \cdot 16100.07047$,

DoI: $10.13140 / \mathrm{RG} \cdot 2 \cdot 2 \cdot 18826 \cdot 36804$,

DOI: $10.13140 / \mathrm{RG} \cdot 2.2 .32248 .14084$.

The aerial photographs are available upon request to the authors.

\section{COPYRIGHT NOTICE}

(c) The Author(s) 2020. This article is distributed under the terms of the Creative Commons Attribution 4.0 International License, which permits unrestricted use, distribution, and reproduction in any medium, provided you give appropriate credit to the original author(s) and the source, provide a link to the Creative Commons license, and indicate if changes were made.

\section{REFERENCES}

Acocella, V., R. D. Lorenzo, C. Newhall, and R. Scandone (2015). "An overview of recent (1988 to 2014) caldera unrest: Knowledge and perspectives". Reviews of Geophysics 53.3, pp. 896-955. Dor: 10.1002/ 2015 rg000492. 
Acocella, V. (2007). "Understanding caldera structure and development: An overview of analogue models compared to natural calderas". Earth-Science Reviews 85.3-4, pp. 125-160. DoI: $10.1016 / \mathrm{j}$. earscirev . 2007.08 .004$.

Barde-Cabusson, S., A. Finizola, A. Peltier, M. Chaput, N. Taquet, S. Dumont, Z. Duputel, A. Guy, L. Mathieu, S. Saumet, F. Sorbadère, and M. Vieille (2012). "Structural control of collapse events inferred by self-potential mapping on the Piton de la Fournaise volcano (La Réunion Island)". Journal of Volcanology and Geothermal Research 209-210, pp. 9-18. Dor: 10 . 1016/j . jvolgeores. 2011.09.014.

Burchardt, S. and T. R. Walter (2010). "Propagation, linkage, and interaction of caldera ring-faults: comparison between analogue experiments and caldera collapse at Miyakejima, Japan, in 2000". Bulletin of Volcanology 72.3, pp. 297-308. Dor: $10.1007 / \mathrm{s} 00445-$ 009-0321-7.

Chandler, B. M. P., D. J. A. Evans, D. H. Roberts, M. Ewertowski, and A. I. Clayton (2016). "Glacial geomorphology of the Skálafellsjökull foreland, Iceland: A case study of 'annual' moraines". Journal of Maps 12.5, pp. 904-916. DoI: $10.1080 / 17445647.2015$. 1096216.

Chaput, M., A. Finizola, A. Peltier, N. Viilleneuve, M. Crovisier, and S. Barde-Cabusson (2019). "Where does a volcano break? Using self-potential reiteration to forecast the precise location of major destructive events on active volcanoes: the case study of the Piton de la Fournaise 2007 caldera collapse". Volcanica 2.2, pp. 151-159. DoI: 10.30909/vol.02.02.151159.

Cole, J., D. Milner, and K. Spinks (2005). "Calderas and caldera structures: a review". Earth-Science Reviews 69.1-2, pp. 1-26. DoI: $10.1016 /$ j . earscirev. 2004 . 06.004.

Coppola, D., D. Piscopo, T. Staudacher, and C. Cigolini (2009). "Lava discharge rate and effusive pattern at Piton de la Fournaise from MODIS data". Journal of Volcanology and Geothermal Research 184.1-2, pp. 174-192. Dor: $10.1016 / \mathrm{j}$. jvolgeores. 2008. 11 . 031.

Delaney, P. T. and D. F. McTigue (1994). "Volume of magma accumulation or withdrawal estimated from surface uplift or subsidence, with application to the 1960 collapse of Kilauea volcano". Bulletin of Volcanology 56.6-7, pp. 417-424. Dor: 10.1007 / bf 00302823 .

Derrien, A. and N. Villeneuve (2018). "Photoscan reports (name convention : YYYYMMDD_DolomieuCrater_Photoscan)". ResearchGate. DOI: $10.13140 /$ RG.2.2.30360.70403, DOI: $10.13140 /$ RG.2.2.27005.26086, DOI: $10.13140 /$ RG.2.2.11905.76647, DOI: $10.13140 /$ RG.2.2.19455.51367, DOI: $10.13140 /$ RG.2.2.16100.07047, DOI: $10.13140 /$ RG.2.2.18826.36804, DOI: $10.13140 /$ RG.2.2.32248.14084. [Datasets].
Derrien, A., N. Villeneuve, A. Peltier, and F. Beauducel (2015). "Retrieving 65 years of volcano summit deformation from multitemporal structure from motion: The case of Piton de la Fournaise (La Réunion Island)". Geophysical Research Letters 42.17, pp. 69596966. DoI: $10.1002 / 2015 \mathrm{gl} 064820$.

Derrien, A., N. Villeneuve, A. Peltier, and L. Michon (2018). "Multi-temporal airborne structure-frommotion on caldera rim: Hazard, visitor exposure and origins of instabilities at Piton de la Fournaise". Progress in Physical Geography: Earth and Environment 43.2, pp. 193-214. Dor: 10.1177/0309133318808201.

Dumont, M., A. Peltier, E. Roblin, P.-A. Reninger, S. Barde-Cabusson, A. Finizola, and V. Ferrazzini (2019). "Imagery of internal structure and destabilization features of active volcano by $3 \mathrm{D}$ high resolution airborne electromagnetism". Scientific Reports 9.1. DOI: $10.1038 / \mathrm{s} 41598-019-54415-4$.

Fontaine, F. R., G. Roult, L. Michon, G. Barruol, and A. D. Muro (2014). "The 2007 eruptions and caldera collapse of the Piton de la Fournaise volcano (La Réunion Island) from tilt analysis at a single very broadband seismic station". Geophysical Research Letters 41.8, pp. 2803-2811. DoI: 10.1002/2014gl059691.

Frankl, A., C. Stal, B. De Wit, A. De Wulf, J. Poesen, and J. Nyssen (2014). "Quantifying the geomorphology of natural hazards: opportunities provided by imagebased 3D modelling and UAVs". eng. Joint Geomorphological meeting, 17th, book of abstracts. Liège, Belgium: International Association of Geomorphologists (IAG), pp. 63-63.

Garden, T. O., D. M. Gravley, B. M. Kennedy, C. Deering, and I. Chambefort (2017). "Controls on hydrothermal fluid flow in caldera-hosted settings: Evidence from Lake City caldera, USA". Geosphere 13.6, pp. 1993-2016. Dor: 10.1130/ges01506.1.

Geshi, N., T. Shimano, M. Nagai, and S. Nakada (2002). "Magma plumbing system of the 2000 eruption of Miyakejima Volcano, Japan”. Bulletin of the Volcanological Society of Japan 47.5, pp. 419-434. DOI: 10.18940/kazan.47.5_419. [In Japanese].

Gouhier, M. and D. Coppola (2011). "Satellite-based evidence for a large hydrothermal system at Piton de la Fournaise volcano (Reunion Island)". Geophysical Research Letters 38.2. DOI: 10.1029/2010gl046183.

Gudmundsson, A. (1988). "Formation of collapse calderas". Geology 16.9, p. 808. DoI: $10.1130 / 0091-$ 7613 (1988) $016<0808$ : focc $>2$. 3 . co; 2 .

Gudmundsson, A., J. Marti, and E. Turon (1997). "Stress fields generating ring faults in volcanoes". Geophysical Research Letters 24.13, pp. 1559-1562. DoI: $10.1029 / 97 \mathrm{gl} 01494$.

Gudmundsson, M. T. et al. (2016). "Gradual caldera collapse at Bárdarbunga volcano, Iceland, regulated by lateral magma outflow". Science 353.6296, aaf8988. Dor: 10.1126/science. aaf8988.

Holohan, E. P., M. P. J. Schöpfer, and J. J. Walsh (2011). "Mechanical and geometric controls on the structural 
evolution of pit crater and caldera subsidence". Journal of Geophysical Research 116.B7. Dor: 10.1029/ $2010 \mathrm{jb} 008032$.

James, M. R., S. Robson, and M. W. Smith (2017). "3$\mathrm{D}$ uncertainty-based topographic change detection with structure-from-motion photogrammetry: precision maps for ground control and directly georeferenced surveys". Earth Surface Processes and Landforms 42.12, pp. 1769-1788. DoI: 10.1002/esp. 4125.

Jaud, M., S. Passot, R. L. Bivic, C. Delacourt, P. Grandjean, and N. L. Dantec (2016). "Assessing the Accuracy of High Resolution Digital Surface Models Computed by PhotoScan ${ }^{\circledR}$ and MicMac ${ }^{\circledR}$ in Sub-Optimal Survey Conditions". Remote Sensing 8.6, p. 465. DoI: $10.3390 / \mathrm{rs} 8060465$.

Kennedy, B., E. Holohan, J. Stix, D. Gravley, J. Davidson, and J. Cole (2018). "Magma plumbing beneath collapse caldera volcanic systems". Earth-Science Reviews 177, pp. 404-424. DoI: $10.1016 / \mathrm{j}$. earscirev. 2017.12 .002 .

Koenderink, J. J. and A. J. van Doorn (1991). "Affine structure from motion". Journal of the Optical Society of America A 8.2, p. 377. Dor: $10.1364 /$ josaa. 8 . 000377.

Lénat, J.-F., P. Bachèlery, and A. Peltier (2012). "The interplay between collapse structures, hydrothermal systems, and magma intrusions: the case of the central area of Piton de la Fournaise volcano". Bulletin of Volcanology 74.2, pp. 407-421. Dor: $10.1007 / \mathrm{s} 00445-$ 011-0535-3.

Lénat, J.-F., D. Fitterman, D. B. Jackson, and P. Labazuy (2000). "Geoelectrical structure of the central zone of Piton de la Fournaise volcano (Réunion)". Bulletin of Volcanology 62.2, pp. 75-89. Dor: 10.1007 / s004459900058.

Lipman, P. W. (1997). "Subsidence of ash-flow calderas: relation to caldera size and magma-chamber geometry". Bulletin of Volcanology 59.3, pp. 198-218. Dor: $10.1007 / \mathrm{s} 004450050186$.

Massin, F., V. Ferrazzini, P. Bachèlery, A. Nercessian, Z. Duputel, and T. Staudacher (2011). "Structures and evolution of the plumbing system of Piton de la Fournaise volcano inferred from clustering of 2007 eruptive cycle seismicity". Journal of Volcanology and Geothermal Research 202.1-2, pp. 96-106. DoI: 10 . 1016/j . jvolgeores. 2011.01.008.

Michon, L., A. Di Muro, N. Villeneuve, C. Saint-Marc, P. Fadda, and F. Manta (2013). "Explosive activity of the summit cone of Piton de la Fournaise volcano (La Réunion island): A historical and geological review". Journal of Volcanology and Geothermal Research 264, pp. 117-133. DoI: 10.1016/j . jvolgeores. 2013. 06 . 012.

Michon, L., F. Massin, V. Famin, V. Ferrazzini, and G. Roult (2011). "Basaltic calderas: Collapse dynamics, edifice deformation, and variations of magma withdrawal". Journal of Geophysical Research 116.B3. DOI: 10.1029/2010jb007636.
Michon, L., T. Staudacher, V. Ferrazzini, P. Bachèlery, and J. Marti (2007). "April 2007 collapse of Piton de la Fournaise: A new example of caldera formation". Geophysical Research Letters 34.21. DoI: 10 . $1029 / 2007 \mathrm{gl031248.}$

Michon, L., N. Villeneuve, T. Catry, and O. Merle (2009). "How summit calderas collapse on basaltic volcanoes: New insights from the April 2007 caldera collapse of Piton de la Fournaise volcano". Journal of Volcanology and Geothermal Research 184.1-2, pp. 138-151. DoI: $10.1016 / \mathrm{j}$. jvolgeores . 2008. 11 . 003.

Muro, A. D., N. Metrich, D. Vergani, M. Rosi, P. Armienti, T. Fougeroux, E. Deloule, I. Arienzo, and L. Civetta (2014). "The Shallow Plumbing System of Piton de la Fournaise Volcano (La Reunion Island, Indian Ocean) Revealed by the Major 2007 Caldera-Forming Eruption". Journal of Petrology 55.7, pp. 1287-1315. Dor: 10.1093/petrology/egu025.

Neal, C. A. et al. (2019). "The 2018 rift eruption and summit collapse of Kīlauea Volcano". Science 363.6425, pp. 367-374. DoI: 10.1126 / science . aav7046.

Peltier, A., V. Famin, P. Bachèlery, V. Cayol, Y. Fukushima, and T. Staudacher (2008). "Cyclic magma storages and transfers at Piton de La Fournaise volcano (La Réunion hotspot) inferred from deformation and geochemical data". Earth and Planetary Science Letters 270.3-4, pp. 180-188. DoI: 10 . 1016/j.epsl.2008.02.042.

Peltier, A., F. Massin, P. Bachèlery, and A. Finizola (2012). "Internal structure and building of basaltic shield volcanoes: the example of the Piton de La Fournaise terminal cone (La Réunion)". Bulletin of Volcanology 74.8, pp. 1881-1897. DOI: 10.1007/ s00445-012-0636-7.

Peltier, A., T. Staudacher, P. Bachèlery, and V. Cayol (2009). "Formation of the April 2007 caldera collapse at Piton de La Fournaise volcano: Insights from GPS data". Journal of Volcanology and Geothermal Research 184.1-2, pp. 152-163. Dor: $10.1016 / \mathrm{j}$. jvolgeores . 2008.09.009.

Roche, O., T. H. Druitt, and O. Merle (2000). "Experimental study of caldera formation". Journal of Geophysical Research: Solid Earth 105.B1, pp. 395-416. DOI: $10.1029 / 1999$ jb900298.

Roult, G., A. Peltier, B. Taisne, T. Staudacher, V. Ferrazzini, and A. D. Muro (2012). "A new comprehensive classification of the Piton de la Fournaise activity spanning the 1985-2010 period. Search and analysis of short-term precursors from a broad-band seismological station". Journal of Volcanology and Geothermal Research 241-242, pp. 78-104. DoI: 10.1016/j . jvolgeores.2012.06.012.

Simkin, T. and K. A. Howard (1970). "Caldera Collapse in the Galapagos Islands, 1968: The largest known collapse since 1912 followed a flank eruption and explosive volcanism within the caldera". Science 
169.3944, pp. 429-437. DoI: $10.1126 /$ science. 169 . 3944.429.

Staudacher, T. (2010). "Field observations of the 2008 summit eruption at Piton de la Fournaise (Ile de La Réunion) and implications for the 2007 Dolomieu collapse". Journal of Volcanology and Geothermal Research 191.1-2, pp. 60-68. DOI: $10.1016 / \mathrm{j}$. jvolgeores.2010.01.012.

Staudacher, T., V. Ferrazzini, A. Peltier, P. Kowalski, P. Boissier, P. Catherine, F. Lauret, and F. Massin (2009). "The April 2007 eruption and the Dolomieu crater collapse, two major events at Piton de la Fournaise (La Réunion Island, Indian Ocean)". Journal of Volcanology and Geothermal Research 184.1-2, pp. 126137. Dor: 10.1016/j . jvolgeores.2008.11.005.

Stix, J., B. Kennedy, M. Hannington, H. Gibson, R. Fiske, W. Mueller, and J. Franklin (2003). "Calderaforming processes and the origin of submarine vol- canogenic massive sulfide deposits". Geology 31.4, p. 375. DOI: $10.1130 / 0091-7613(2003) 031<0375$ : cfpato $>2.0$. co;2.

Tulet, P. and N. Villeneuve (2011). "Large scale modeling of the transport, chemical transformation and mass budget of the sulfur emitted during the April 2007 eruption of Piton de la Fournaise". Atmospheric Chemistry and Physics 11.9, pp. 4533-4546. DoI: 10 . 5194/acp-11-4533-2011.

Urai, M., N. Geshi, and T. Staudacher (2007). "Size and volume evaluation of the caldera collapse on Piton de la Fournaise volcano during the April 2007 eruption using ASTER stereo imagery". Geophysical Research Letters 34.22. DoI: 10.1029/2007gl031551.

Walker, G. P. L. (1984). "Downsag calderas, ring faults, caldera sizes, and incremental caldera growth". Journal of Geophysical Research 89.B10, p. 8407. Dor: 10 . 1029/jb@89ib10p08407. 